\title{
Benign Childhood Germ Cell Tumor
}

National Cancer Institute

\section{Source}

National Cancer Institute. Benign Childhood Germ Cell Tumor. NCI Thesaurus. Code C6553.

A non-metastasizing germ cell tumor that occurs during childhood. 